Meta

Journal des traducteurs

Translators' Journal

\title{
Codifying conceptual information in descriptive terminology management
}

\section{Pamela Faber et Maribel Tercedor Sánchez}

Volume 46, numéro 1, mars 2001

Traduction médicale et documentation / Medical translation and documentation

URI : https://id.erudit.org/iderudit/002715ar

DOI : https://doi.org/10.7202/002715ar

Aller au sommaire du numéro

Éditeur(s)

Les Presses de l'Université de Montréal

ISSN

0026-0452 (imprimé)

1492-1421 (numérique)

Découvrir la revue

Citer cet article

Faber, P. \& Tercedor Sánchez, M. (2001). Codifying conceptual information in descriptive terminology management. Meta, 46(1), 192-204.

https://doi.org/10.7202/002715ar
Résumé de l'article

Le Modèle lexèmatique fonctionnel (MLF), créé par Martín Mingorance, et la Théorie Sens-Texte (MTT) de Mel'cuk sont deux modèles de description lexicale complémentaires qui peuvent être appliqués à la formalisation et à la codification de l'information terminologique. Le MLF est compatible avec la théorie générale de la terminologie, car il poursuit la structuration onomasiologique du lexique, en ce qui concerne l'aire du signifié ou les domaines lexicaux. Quant au MTT, il a une applicabilité terminologique, en utilisant les fonctions lexicales, pour représenter l'information syntagmatique et paradigmatique des textes spécialisés. Grâce à la combinaison de ces deux modèles, on peut élaborer une méthodologie permettant un emploi simple de la structure des domaines spécialisés aux non-spécialistes et offrant la formalisation de différents types d'information terminologique aux traducteurs. 


\title{
Codifying conceptual information in descriptive terminology management
}

\author{
PAMELA FABER \\ MARIBEL TERCEDOR SÁNCHEZ \\ Universidad de Granada, Granada, España
}

\section{RÉSUMÉ}

Le Modèle lexèmatique fonctionnel (MLF), créé par Martín Mingorance, et la Théorie Sens-Texte (MTT) de Mel'cuk sont deux modèles de description lexicale complémentaires qui peuvent être appliqués à la formalisation et à la codification de l'information terminologique. Le MLF est compatible avec la théorie générale de la terminologie, car il poursuit la structuration onomasiologique du lexique, en ce qui concerne l'aire du signifié ou les domaines lexicaux. Quant au MTT, il a une applicabilité terminologique, en utilisant les fonctions lexicales, pour représenter l'information syntagmatique et paradigmatique des textes spécialisés. Grâce à la combinaison de ces deux modèles, on peut élaborer une méthodologie permettant un emploi simple de la structure des domaines spécialisés aux non-spécialistes et offrant la formalisation de différents types d'information terminologique aux traducteurs.

\section{ABSTRACT}

Martín Mingorance's Functional-Lexematic Model (FLM) and Mel'cuk's Meaning Text Theory (MTT) are two complementary models of lexical description, which can also be applied to the description of terminological information. The FLM is compatible with general terminology theory because it envisions a lexicon structured onomasiologically in terms of areas of meaning or lexical domains. The MTT is also applicable because its lexical functions can be used to represent both paradigmatic and syntagmatic information within specialized texts. The combination of these two models permits the formalization of different translation-oriented types of terminological information, and is an aid to non-specialists who need to structure a specialized field.

\section{MOTS-CLÉS/KEYWORDS}

translation, terminology, Functional-Lexematic Model (FLM), Meaning Text Theory (MTT)

\section{Introduction}

The representation of conceptual structures in a specialized domain is an essential part of terminology processing for translators who must rapidly acquire expert knowledge in order to translate specialized texts. However, despite its evident importance, terminology textbooks are not very forthcoming when it comes to describing exactly how such an activity should be carried out. Though there is general consensus as to its importance, rarely is an effort made to describe exactly how to elaborate the macrostructure of specialized domains as well as how to ascertain the types of information that should be included within the micro-representation of each concept. Perhaps one reason for this apparent gap is the fact that the very complexity of the process defies a unitary description because there is more than one way of estab-

Meta, XLVI, 1, 2001 
lishing conceptual organization (Meyer and Mackintosh 1996) ${ }^{1}$. If this is the case, then the only possible means of description is to point out different avenues that translators/terminologists can explore to carry out their work in the acquisition of specialized knowledge.

The organization of concepts in translation-oriented terminology management is a tool to facilitate knowledge acquisition. As might be supposed, this does not only mean consulting an expert, compiling texts in which the terms are used, and/or looking them up in different kinds of technical dictionaries in order to organize them in sets. On the one hand, it signifies integrating concepts in already existing cognitive structures, and on the other hand, the recognition and representation of both hierarchical and non-hierarchical relations which the new concept establishes with others.

It is well-known that, in traditional terminology processing, the representation of concepts normally is carried out in the form of taxonomies based on TYPE-OF and PART-OF relations. Evidently, these types of relation are essential in the generation of ontologies of concepts, and necessarily underlie any conceptual representation. However, the structuring of concepts in hierarchies provides a very restricted vision of a concept, which as a mental construct, should be conceived as multidimensional (Kageura 1997; Bowker 1997; Wright 1997).

The fact that concepts possess multiple facets means that the translator must be able to assimilate knowledge from various perspectives. For a terminographic representation to be effective, it must encode a variety of information, which basically corresponds to the different perceptual, logical, and linguistic formats that our mind uses for storing data.

\section{Objectives}

The aim of the present study is to establish the basis for more complete terminographic description and representation, allowing for linguistic and non-linguistic relations of terms within one domain and in relation with other domains. For such a representation, it is productive to use the distinction made by Dubuc and Lauriston (1997), which differentiates the term in vitro from the term in vivo:

- The term in vivo represents the concept as it is used in texts. This type of information is the first that a translator receives about the term. This is essentially contextual information, as well as the relations which the term activates with others within the same text. The information that the translator perceives in the text obliges him or her to evaluate what type of terminological knowledge is activated and also to arrive at conclusions about the text as a whole.

- The term in vitro represents the concept as the sum of all the information that it can potentially activate in a discourse. In other words, it concerns our predictions regarding the behavior of a particular term in a specific communicative situation.

- The term in situ is a third type of information that we have included. This means considering the term as part of an event. This type of information falls outside of the in vivo / in vitro distinction, but is also essential because it underlines the necessity of situating the term in the context of larger knowledge structures (i.e. frames), which codify types of event [medical, legal, military, religious, etc.]. This characteristic is essential for the understanding of metaphorical terms, neologisms, and interdisciplinary borrowings. 
It is on the combination of in vivo, in vitro, and in situ states that we have focused our study, through the application of the following methodological approaches.

\section{Theoretical principles: description and application}

The organization of concepts is an activity whose meaningfulness can only be enhanced when carried out in a principled way. The application of linguistic theories to translation and terminology has not always generated positive results. Evidently, a linguistic model based on the formalization of grammatical structures has a very limited value in translation and terminology, in which the emphasis is on meaning. For this reason, linguistic theories applicable to terminology are those that come to grips with semantics, and which can be used for the representation of lexical as well as terminological knowledge. This is especially important in terminology in which the representation of conceptual relations is so crucial.

In consonance with this, we explore the application of two lexically-based theories in the codification of specialized knowledge: Mel'euk's $(1981,1988,1996)$ Meaning-Text Theory (MTT) and Martín Mingorance's (1984, 1989, 1995; Faber and Mairal 1999) Functional-Lexematic Model (FLM). Both are lexicological and can be used as a means of representing conceptual and collocational relations in general and specialized language.

\subsection{Application of the Functional-Lexematic Model (FLM) to terminology description}

The organization that the FLM proposes for the lexicon is partly based on the distinction between syntagmatic and paradigmatic relations, or the complementary principles of combination and selection (Saussure 1916; Lyons 1977: 241). This distinction is highly relevant because it is found in conceptual organization prior to and independently of the linguistic system (Nelson 1985: 179).

The paradigmatic axis of the FLM lexicon not only codifies how terms are arranged on the axis of selection, organizing them onomasiologically in a hierarchy of domains and subdomains, but is also a determining factor in their syntax or combinatorial possibilities, a crucial issue for translators, who must generate target texts in which these terms are correctly used. As shall be seen, it thus offers the possibility of combining the in vivo and in vitro information, using their convergence as the basis of conceptual structure.

This type of relational approach focuses on conceptual areas, and accepts the supposition that there are common properties that bind the items in a domain together as well as properties that differentiate them from each other. Such a model is in consonance with the representation of human semantic memory as a network in which a node is a concept and concepts are linked together by a variety of different types of relations (Iris, Litowitz and Evens 1988: 263).

The problem is how to arrive at the type of conceptual organization that most approximates the storage of semantic information in our mind. One method that is often followed is the elaboration of a list of domains and subdomains ad hoc. Terms/ lexical items are then assigned to the categories whose meaning seems to best match with their own. However, although this type of top-down method is the one followed 
in the elaboration of thesauri and large-scale lexical databases, it is both time consuming and not necessarily the best way of arriving at a useful type of organization for translation.

Terminology management is not a process that can be $100 \%$ top-down or bottomup; rather it should be a mixture of the two. This is due to the fact that a terminological domain cannot be represented as a totally open or closed system. Specialized knowledge is a subdivision of our general knowledge system with flexible cognitive schemas, which allows the manipulation of ideas and the construction of hypotheses. However, such schemas cannot be totally without constraints, and thus imply a welldefined system of attributes, entities and relations (Sager 1990: 13). In terminology, this means the specification of a metalanguage, consisting of a conceptual structure with pre-established relations between concepts, which is reflected in the definition of each term. In this sense, definitions can be regarded as the bridge between concepts and terms, and thus are truly considered the custodians of knowledge (Sager 1990).

The FLM is a linguistic way of organizing concepts, using the specialized information provided by specialists in the form of well-structured terminographic definitions. As Béjoint (1997: 19-20) observes, definitions have not been given their due importance in terminology. Terminological definitions are often treated as given information instead of a construction. However, reality shows us that different specialists, depending on their specialization and interests, can have different ways of envisioning the same reality, something which explains the radical difference in the structure and length of definitions of the same concept. This can be seen in the following definitions of adenocarcinoma:

(1) ADENocARcinoma A malignant tumor with cells arranged in a glandlike pattern. (The HarperCollins Illustrated Medical Dictionary)

(2) adenocarcinoma A cancer made up of abnormal gland cells on the lining or inner surface of an organ. It can develop in virtually any part of the body. Adenocarcinomas may develop in the lung, pancreas, breast, prostate, esophagus, stomach, vagina, urethra, and small intestine, among others. (The Cancer Dictionary)

(3) AdENocarcinoma A malignant growth of glandular tissue. This tissue is widespread throughout the body's organs and the tumours may occur, for example, in the stomach, ovaries, and uterus. Adenocarcinomas may be subdivided into those that arise from mucous or serous secreting glandular tissue. (Black's Medical Dictionary)

These definitions illustrate how the same concept is represented differently by different specialists, in this case, by progressively adding more information facets:

Table 1: Comparative dictionary information

\begin{tabular}{|l|l|l|l|}
\hline & $\begin{array}{l}\text { The HarperCollins } \\
\text { Illustrated Medical } \\
\text { Dictionary }\end{array}$ & The Cancer Dictionary & Black's Medical Dictionary \\
\hline Conceptual label & malignant tumor & $\begin{array}{l}\text { cancer } \\
\text { [type] abnormal } \\
\text { gland cells }\end{array}$ & $\begin{array}{l}\text { malignant growth } \\
\text { [type] glandular tissue }\end{array}$ \\
\hline Form & $\begin{array}{l}\text { cell arrangement } \\
\text { in glandlike pattern }\end{array}$ & - & - \\
\hline
\end{tabular}




\begin{tabular}{|l|l|l|l|}
\hline Location & - & $\begin{array}{l}\text { on the lining or inner } \\
\text { surface of any organ, } \\
\text { e.g. lung, pancreas, } \\
\text { breast, prostate, } \\
\text { esophagus, stomach, } \\
\text { vagina, urethra, and } \\
\text { small intestine }\end{array}$ & $\begin{array}{l}\text { where there is glandular } \\
\text { tissue, e.g. stomach, } \\
\text { ovaries, uterus }\end{array}$ \\
\hline Classification & & $\begin{array}{l}\text { (i) mucous secreting } \\
\text { glandular tissue } \\
\text { (ii) serous secreting } \\
\text { glandular tissue }\end{array}$ \\
\hline
\end{tabular}

Evidently, in order to obtain a more complete picture of a concept, it is best to use more than one source from which to extract essential information. Other problems with such terminological repositories are the wide variety of definition formats that can be found as well as the lack of entries for compound terms and phrases.

The FLM codifies lexical/terminological units onomasiologically in a hierarchy of domains and subdomains. This type of organization is based on definitional analysis. Units with definitions having the same genus belong to the same domain or subdomain. It has been successfully applied to the verb lexicon:

Table 2: Acquisition phase of possession (Faber and Mairal 1999: 102)

HAVE
TO HAVE SOMETHING
possess to have something [formal].
To COME TO HAVE sOMETHING
get to come to have something as a result of some previous activity.
gain to get something wanted/beneficial through effort.
win to gain something by work/struggle/skill.
obtain to get something as a result of work/planning.
procure to obtain something difficult to find [formal].
acquire to obtain something with effort, adding it to previous possessions.
To GET MONEY
FOR sOMETHING DONE
earn to get money as payment for work done.
FROM somEBODY
extort to get money from somebody by force/threats.
collect to get money from a number of people/places.
To GET somETHING BY PAYING MONEY FOR IT
buy to get something by paying money for it.
purchase to buy something [formal].

In Table 2, the genus is have, and all the other verbs are defined in terms of it. The adverbial modification in each definition encodes the parameters within each domain and subdomain. In this particular hierarchy, get is the most direct hyponym of have, and thus becomes the genus of other verbs at more specific levels of the hierarchy. To come to have is the phrase that labels the lexical subdomain in question. 
The application of the FLM to specialized knowledge means using it to organize nominal forms. However, the essential principle of keeping the genus consistent in hierarchies of related terms is the same. In terminology, compound terminological units often result from a meronymic or PART-OF relation with the base concept from which they are derived. The concepts they represent encode multilevel information. In Table 3, such information is segmented in such a way as to underline the hierarchical relations of the concept system, which is evident in the definition structure of the terms:

Table 3: Definitional hierarchy of MALIGNANT NEOPLASMS

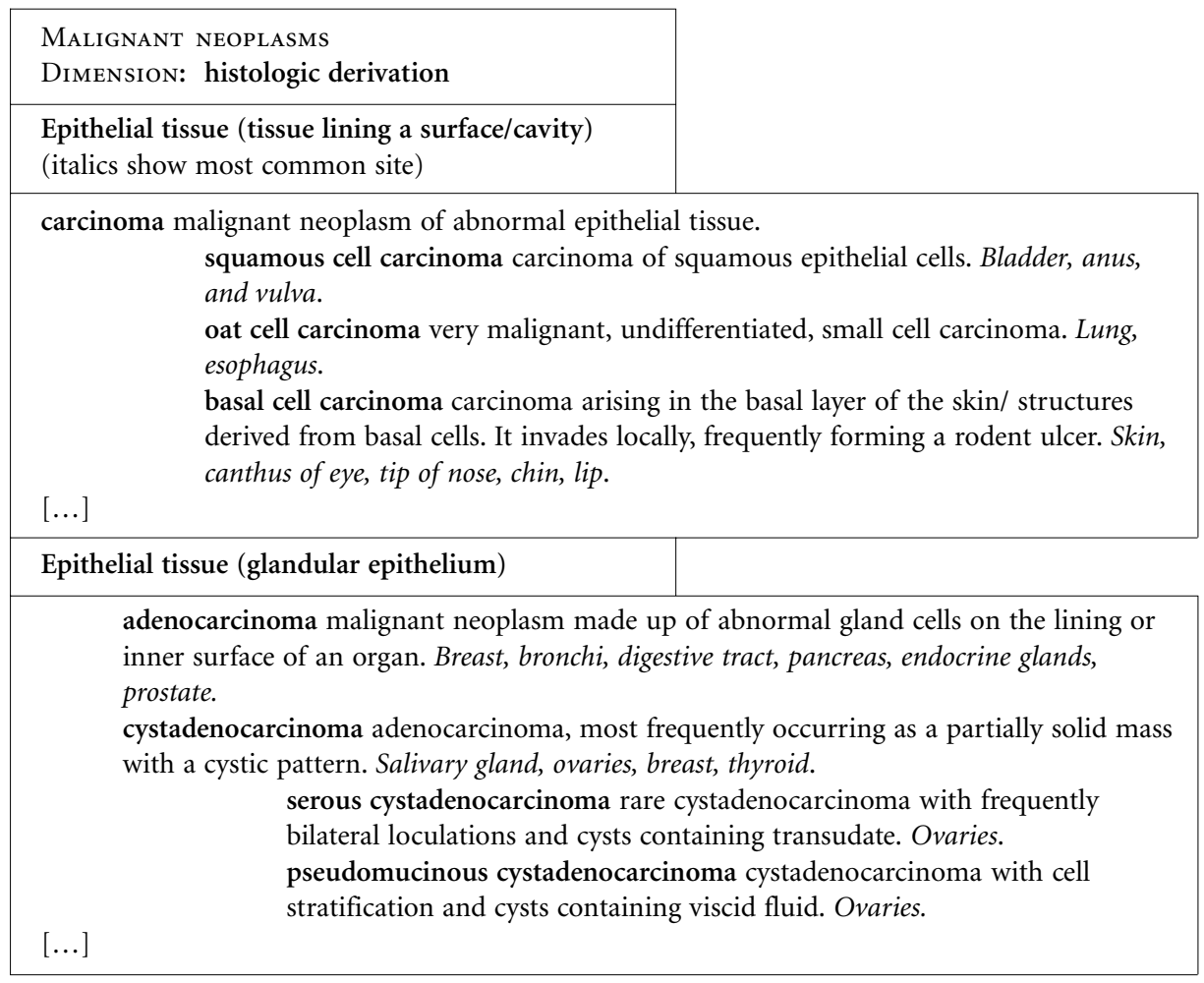

The ISA relation is represented by the genus or conceptual label in each definition. For example, table 3 indicates that serous cystadenocarcinoma and pseudomucinous cystadenocarcinoma are both types of cystadenocarcinoma. Cystadenocarcinoma is in turn a type of adenocarcinoma, which is a type of malignant neoplasm. It is true that in this particular example, the terminological chain is also evident in the term itself, but this is not always the case.

The tracing and construction of lexical hierarchies through the analysis of dictionary definitions in itself is not new. Amsler (1980) did precisely that in order to derive hyponymic information about general language nouns. The basic premise is that the information in dictionaries constitutes a huge relational network or grid, which must necessarily have a non-trivial correspondence with the knowledge being expressed. These chains reveal the properties of knowledge specified in the differentiating information of the more general words in these chains, so that they can be 
inherited by the more specific words (Meijs and Vossen 1992: 144-145). In WordNet, lexical hierarchies have also been reconstructed by following the trail of hypernomically related synsets of general language words:

(4) \{robin, redbreast\}@ $\varnothing\{$ bird $\} @ \varnothing$ animal, animate_being $\}$ (Miller 1998: 25)

As has been shown in Table 3, exactly the same thing can be done for terms. In fact, if the chain is carried even farther, it shows the connection of specialized language to general language within the larger context of an ontology of concepts. What terminologists often gloss over is the fact that terms are also linguistic forms, and that at their most superordinate levels, conceptual hierarchies with terminological labels become general language lexical items:

(5) $\{$ small cell lung cancer $\}\} @ \varnothing$ lung cancer $\} @ \varnothing\{$ cancer $\} @ \varnothing\{$ disease $\} @$ $\varnothing\{$ event $\} @ \varnothing\{$ ALL $\}$

At some point, specialized language shades off into general language and it is not always easy to determine where specialized language stops and where general language begins. Language is a dynamic system, and in the same way that general language items are imported into specialized language to designate concepts, exactly the opposite can happen as well. Terms can be exported into general language. One finds terms like hemorrhage, which were initially specialized language, but then entered general language through metaphorical extension:

(6) hem•or•rhage (hem, $f \mathrm{r}$ ij, hem,rij) n., v., -rhaged, -rhag•ing - n.1. a profuse discharge of blood. 2. the loss of assets, esp. in large amounts. - v.i.3. to bleed profusely. 4. to lose assets, esp. in large amounts. - v.t.5. to lose (assets): The company was hemorrhaging cash. [1665-75; < L haemorrhagia < Gk haimorrhagía. See HEMO-, -RRHAGIA] (Random House Webster's Electronic Dictionary and Thesaurus)

As shown in (6), the initial meaning of hemorrhage as an important loss of blood has been metaphorically extended to general language to mean an important loss of money. The correspondence between blood and money is implicit in the fact that both fill the same argument slot and semantic role in the definition, in other words, both can be considered as part of the same event, having therefore an in situ correspondence.

The structural organization afforded by the FLM allows the construction of definitions, which systematize expert knowledge, and permits the formalization of terminological chains, joined by the genus/nuclear term of their definitions. In this sense, it is possible for translators/terminologists to construct ISA or PARTOF hierarchies of terms, as well as to segment the differential information in the definitions into categories of non-hierarchical relations, which as shall be seen, can be formalized by using Mel'euk's lexical functions.

\subsection{Description and application of Mel'euk's lexical functions}

Both paradigmatic and syntagmatic information of terms can be formalized using Mel'euk's Meaning-Text Theory (MTT). It is somewhat different from the FLM approach, though there are many areas of convergence. 
One of the most distinctive aspects of MTT, and an important part of its level of semantic description is its inventory of lexical functions (LFs), which codify different types of semantic and syntactic relations. According to Mel'euk (1996: 39), a lexical function $\mathrm{f}$ is a correspondence that associates a given lexical expression $\mathrm{L}$ with a set of lexical items $L_{1}$ which express a specific meaning associated with $f$. This can be represented by the following formula: $\mathrm{f}(\mathrm{L})=\mathrm{L}_{1}$.

Mel'cuk defines close to sixty lexical functions and, using Saussure's dichotomy, divides them into two types: paradigmatic LF relations and syntagmatic LF relations. Paradigmatic LFs associate with a keyword a set of lexical items that share a nontrivial semantic component, and include all contrast and substitution relations between lexical items in specific contexts. A few examples of such functions, some of which coincide with sense relations, can be seen in Table 4, in which they have also been applied to specialized language:

Table 4: Paradigmatic lexical functions in general and specialized language

\begin{tabular}{|c|c|}
\hline General Language & Specialized Language \\
\hline Gener $($ republic $)=$ state & $\begin{array}{l}\text { Gener }(\text { magnetic resonance })=\text { diagnostic test } \\
\text { Gener }(\text { small cell lung cancer })=\text { lung cancer }\end{array}$ \\
\hline Syn $($ start $)=$ begin & $\begin{array}{l}\text { Syn }_{1}(\text { small cell lung cancer })=\text { non-differentiated small cell lung } \\
\text { cancer } \\
\text { Syn }_{2}(\text { small cell lung cancer })=\text { microcytic carcinoma of the lung }\end{array}$ \\
\hline Anti $($ joy $)=$ grief & Anti $($ malignant $)=$ benign \\
\hline Contr $($ fire $)=i c e$ & $\begin{array}{l}\text { Contr }_{1}(\text { small cell lung cancer })=\text { non-small cell lung cancer } \\
\text { Contr }_{2}(\text { small cell lung cancer })=\text { non-microcytic lung carcinoma }\end{array}$ \\
\hline
\end{tabular}

The lexical function Gener (Table 4) not only covers hyponymic institutional relations, but also the relation between a lexeme and its closest generic concept, which can be used as an attributive modifier. In the case of terms, this function can be used to codify the description of magnetic resonance as a type of diagnostic test and small cell lung cancer as a type of lung cancer. Mel'euk specifies different types of antonymy, but generally this relation in MTT is the result of the semantic decomposition of lexical units, as seen in their respective definitions.

Syn is used for synonymy relations. In specialized language it can be used to codify terminological variation (paraphrasing, metaphoric substitution), something frequent in medical terminology.

In Table 4, joy is considered antonymous (Anti) to grief because the former is defined as a pleasant emotion, and the latter, as an unpleasant emotion. In the example, the opposition between pleasant and unpleasant is thus the basis for antonymy (Wanner 1996b: 8). This can also be applied to specialized language. Accordingly, benign is the opposite of malignant because it can be used to describe a disease that does not endanger life, while malignant refers to a condition which does endanger life. The basis for antonymy is derived from the opposition between lifethreatening and non life-threatening.

The contrastiveness relation (Contr) is different from traditional antonymy in that it does not necessarily entail a logical opposition between the lexical units con- 
cerned. The example in Table 4 shows the contrastiveness relation in the sense of Apresjan's modal antonyms (Wanner 1996b: 9). This relation is useful in the description of terminological units, which appear to be in opposition to each other within the concept system, but are not really antonymous.

Syntagmatic LFs formalize a semantic relation between two lexemes $\mathrm{L}_{1}$ and $\mathrm{L}_{2}$, which is instantiated in the textual string in a non-predictable way. Such a relation is non-predictable when the co-occurrence of one cannot be derived from the semantic selection restrictions of the other, but rather has to be learned as an instantiation of a specific syntagmatic relation. Examples of such functions can be seen in the following:

Table 5: Syntagmatic lexical functions in general and specialized language

\begin{tabular}{|c|l|}
\hline General Language & Specialized Language \\
\hline Magn $($ naked $)=$ stark & $\begin{array}{l}\text { Magn }(\text { dose })=\text { high }[\text { TREATMENT]: } \\
\text { chemotherapy/radiotherapy] }\end{array}$ \\
\hline Pejor $($ housewife $)=$ nagging & Pejor $($ tumor $)=$ aggressive \\
\hline Instr $($ satellite $)=$ via $_{\text {Func }_{1}\left(\text { snow }_{\mathrm{N}}\right)=\text { falls }}^{\text {Instr }(\text { endoluminal })=\text { via }}$ \\
\hline & Func $_{1}($ tumor $)=$ grows/spreads/disseminates \\
\hline
\end{tabular}

For example, the lexical function Magn in Table 5 is an attributive relation between two lexical units, and codifies the highest degree of the semantic content in question. Nakedness always means not having clothes on, but being stark naked is the total absence of any covering/clothing whatsoever, probably within a context that makes this state seem even more surprising than usual, and here it is most likely that relevant in vitro information regarding this phrase be activated. This same function can be applied to dose within the context and category of treatment. Although the concept of contextual frame is not yet formally contemplated within $\mathrm{MTT},{ }^{2}$ we have added this specification within brackets.

Pejor is the opposite of Bon, and is a shorter way of representing the Complex LF MinusBon (Mel'euk 1996: 57). It is used to denote the speaker's negative evaluation of the lexical/terminological unit in question. Evidently, the LF Bon, which encodes positive evaluation, is not relevant to tumor because of the concept's inherent negativity.

Instr signifies by means of. In the case of satellite in general language and endoluminal in specialized language, the instrument relation is indicated by via since this is the collocation most often used with these units to indicate such a relationship.

Another example of a syntagmatic lexical function is that of Func, which codifies a type of noun-verb collocation indicating performance. In the general language example, the verb that generally collocates with snow is fall because this is the action usually associated with it. As shown in Table 5, this function can also be extended to specialized language. However, we have included more than one result.

Syntagmatic lexical functions can be used to describe collocations and phrases in terminology. Their helpfulness resides in the fact that they codify the existence of strong collocators for a particular base, something which is extremely important in the writing of scientific texts. The viability of this theory and its application to lexical 
description has been pointed out by Wanner (1996b: 12): "Unlike in Case theories, in MTT, valency is not a distinctive characteristic of verbs only, but is characteristic of all predicates, i.e. many adjectives, nouns, etc."

The fact that it can be applied to all types of predicates makes it especially useful in the representation of terminological information in which the majority of the terms are nouns or nominal compounds as well as adjectives. The usefulness of this type of representation in terminology is obvious, since it formalizes both paradigmatic relations and syntagmatic collocations.

Lexical functions constitute a linguistic base for knowledge representation (Heylen 1995: 134). In this sense, they can be used in the generation of ontologies and knowledge bases, as well as text generation tools. However, for our purposes, their greatest usefulness lies in the formalization of collocations in specialized texts, which also coincides in many respects with the differentiating information in dictionary definitions.

Apart from the LFs already mentioned (Anti, Syn, Contr), others that can be applied to the description of terminological units in the field of oncology are the lexical functions $S_{\text {instr }}, S_{\text {loc }}, S_{\text {mode }}, S_{\text {med }}, S_{\text {res }}$, which are specific of nominal forms $(S)$ and generate the standard name of Instrument, Location, Mode, Means, and Result of the situation denoted by L. In General Language, L refers to a situation. In the specialized language examples, we have applied it to the field of MEDical onCOLOGY, and have represented cancer as a DISEASE-EVENT.

Table 6: Lexical functions used in the representation of DISEASE-EVENT

\begin{tabular}{|l|l|l|l|}
\hline $\begin{array}{l}\text { MTT LEXICAL } \\
\text { FUNCTION }\end{array}$ & $\begin{array}{l}\text { GENERAL } \\
\text { LANGUAGE }\end{array}$ & \multicolumn{2}{l|}{ SPECIALIZED LANGUAGE: ONCOLOGY } \\
\hline $\mathrm{S}_{\text {loc }}$ & typical location & typical location(s) & body-part where the tumor is located \\
\hline $\mathrm{S}_{\text {instr }}$ & typical instrument & typical diagnostic test(s) & instrument used to diagnose tumor \\
\hline $\mathrm{S}_{\text {mode }}$ & typical mode & typical treatment(s) & mode used to cure tumor \\
\hline $\mathrm{S}_{\text {med }}$ & typical means & typical risk factor $(\mathrm{s})$ & means which facilitate tumor forms \\
\hline $\mathrm{S}_{\text {res }}$ & typical result & typical symptom $(\mathrm{s})$ & physical result of the tumor \\
\hline
\end{tabular}

For example, the MTT representation of these categories as applied to small-cell lung cancer (SCLC) would be the following:

(7) [AFFECTED BODY-PART]

$\mathrm{S}_{\mathrm{loc}}(\mathrm{SCLC})=$ lung

(8) [RISK FACTOR]

$\mathrm{S}_{\text {medl }}($ SCLC $)=$ smoking

$\mathrm{S}_{\text {med2 } 2}(\mathrm{SCLC})=$ diesel engine exhaust gas

$\mathrm{S}_{\text {med3 }}(\mathrm{SCLC})=$ exposure $\varnothing$ (i) asbestos and organic chemical products

(ii) radiation

(9) [sумРтом]

(iii) radon

$\mathrm{S}_{\text {resl }}$ (SCLC) $\mathrm{A}_{1} \mathrm{~S}_{1}=$ persistent cough

$\mathrm{S}_{\text {res2 } 2}(\mathrm{SCLC}) \mathrm{S}_{1} \mathrm{~S}_{1}=$ bleeding expectoration

$\mathrm{S}_{\text {res3 }}(\mathrm{SCLC}) \mathrm{S}_{1}$ = difficult breathing

$\mathrm{S}_{\text {rest }}(\mathrm{SCLC})=$ pain $\quad \varnothing$ (i) $\mathrm{S}_{\text {locl }}$ (pain) $=$ chest

(ii) $\mathrm{S}_{\mathrm{loc} 2}($ pain $)=$ shoulder 


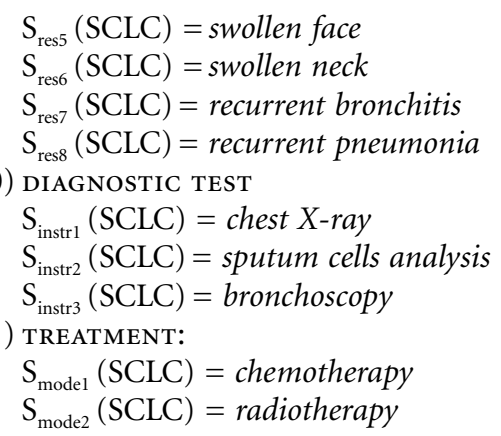

The application of LFs to terminological data allows for a succinct and coherent way of describing collocational data and storing it for further computational treatment.

\section{Conclusions}

The dictionary meaning of terminological units is a resource that could be further exploited in terminology management. The role of definitions in the representation of specialized knowledge is a significant one because if the definition is elaborated coherently, it acts as a pointer to both hierarchical and non-hierarchical relations between concepts within the same subject field. Possibly one reason why definitions have not been given their due importance is the fact that such a consideration implies the use of a principled model of lexicographic description, and terminologists have been generally reticent to use lexicological models.

Two complementary models of lexical description are the FLM and the MTT, both of which can be applied to the description of terminological units. The FLM is compatible with general terminology theory because it envisions a lexicon structured onomasiologically in terms of areas of meaning or lexical domains. Accordingly, its principles of definitional analysis can be applied to help structure specialized knowledge. The MTT is also applicable because its lexical functions can be used to represent both paradigmatic and syntagmatic information within specialized texts. This can be especially useful in the formalization of collocational data.

The combination of these two models allows for the description of concepts in a multilevel and multidimensional way, permitting translators/terminologists the rapid acquisition of specialized knowledge of a particular domain and in relation with other domains, through the specification of in vivo, in situ, and in vitro relations.

\section{NOTES}

1. This has also been observed by Cabré (1999: 69-176), who advocates a Communicative Theory of Terminology, which accounts for terminological variants, contextual diversity, and pragmatic features.

2. The closest correspondence to frame within MTT is notion as proposed by Escalier and Fournier (1997: 49). According to them, notion "allows to gather under the same label different lexemes, syntactic constructions or grammatical elements that are related by a non-strict equivalence relation in a certain context. In other words, it constitutes an abstraction on the lexemes which it refers to." 


\section{REFERENCES}

Altman, R. and M. J. Sarg (1992): The Cancer Dictionary, New York, Facts on Life.

Amsler, R. A. (1980): “The Structure of the Merriam-Webster Pocket Dictionary," Technical Report, TR-164, University of Texas at Austin.

BÉjoint, H. (1997): «Regards sur la définition en terminologie», Cahiers de lexicologie, 70-1, p. 19-26.

Bowker, L. (1997): "Multidimensional Classification of Concepts and Terms," Handbook of Terminology Management (S. E. Wright and G. Budin, eds.), Amsterdam and Philadelphia, John Benjamins, pp. 133-146.

CABré, M. T. (1999): La terminología: Representación y comunicación, Barcelona, Institut Universitari de Lingüística Aplicada (Universitat Pompeu Fabra).

Dox, I. G., B. J. Melloni and G. M. Eisener (1993): The HarperCollins Illustrated Medical Dictionary, New York, HarperCollins.

Dubuc, R. and A. Lauriston (1997): “Terms and Contexts," Handbook of Terminology Management (S. E. Wright and G. Budin, eds.), Amsterdam and Philadelphia, John Benjamins, pp. $80-88$.

Escalier, M.-C. and C. Fournier (1997): "Towards a Notional Representation of Meaning in the Meaning-Text Model: The Case of the French sI," Recent Trends in Meaning-Text Theory (L. Wanner, ed.), Amsterdam and Philadelphia, John Benjamins, pp. 25-55.

Faber, P. and R. Mairal Usón (1999): Constructing a Lexicon of English Verbs, Berlin, Mouton de Gruyter.

Heylen, D. (1995): "Lexical Functions, Generative Lexicons and the World," Computational Lexical Semantics (P. Saint-Dizier and E. Viegas, eds.), Cambridge, Cambridge University Press, pp. 125-140.

Iris, M., B. Litowitz and M. Evens (1988): "Problems of the part-whole relation," Relational Models of the Lexicon: Representing Knowledge in Semantic Networks (M. Evens, ed.), Cambridge, Cambridge University Press, pp. 261-287.

Kageura, K. (1997): "Multifaceted/Multidimensional Concept Systems," Handbook of Terminology Management (S. E. Wright and G. Budin, eds.), Amsterdam and Philadelphia, John Benjamins, pp. 119-132.

Lyons, J. (1997): Semantics, 1/2, London, Cambridge University Press.

Macpherson, G., ed. (1995): Black's Medical Dictionary, Lanham (Maryl.), Barnes \& Noble.

Martín Mingorance, L. (1984): "Lexical Fields and Stepwise Lexical Decomposition in a Contrastive English-Spanish Verb Valency Dictionary," LEX'eter' 83: Proceedings of the International Conference on Lexicography (R. Hartmann, ed.), Tübingen, Niemeyer, pp. 226-236.

- (1990): "Functional Grammar and Lexematics," Meaning and Lexicography (J. Tomaszczy and B. Lewandowska-Tomaszczy , eds.), Amsterdam and Philadelphia, John Benjamins, pp. 227-253.

- (1995): "Lexical Logic and Structural Semantics: Methodological Underpinnings in the Structuring of a Lexical Database for Natural Language Processing," Panorama der Lexikalischen Semantik (U. HoInkes, ed.), Tübingen, Gunter Narr, pp. 461-474.

Meijs, W. and P. Vossen (1992): "In so Many Words: Knowledge as a Lexical Phenomenon," Lexical Semantics and Knowledge Representation (J. Pustejovsky and S. BergLER, eds.), Berlin, Springer, pp. 137-153.

Mel'euk, I. (1981): “Meaning-Text Models: A Recent Trend in Soviet Linguistics," Annual Review of Anthropology, 10, pp. 27-62.

— (1988): "Semantic Description or Lexical Units in an Explanatory Combinatorial Dictionary: Basic Principles and Heuristic Criteria," International Journal of Lexicography, 1-3, pp. 165188.

- (1996): "Lexical Functions: A Tool for the Description of Lexical Relations in the Lexicon," Recent Trends in Meaning-Text Theory (L. WAnner, ed.), Amsterdam and Philadelphia, John Benjamins, pp. 37-71. 
Meyer, I. and K. Mackintosh (1996): "Refining the Terminographer's Concept-Analysis Methods: How can Phraseology Help?," Terminology, 3-1, pp. 1-26.

Miller, G. A. (1998): “Nouns in WordNet,” WordNet: An Electronic Lexical Database (C. Fellbaum, ed.), Cambridge (Mass.), MIT Press, pp. 23-46.

Nelson, K. (1985): Making Sense: The Acquisition of Shared Meaning, Orlando, Academic Press.

Random House Webster's Electronic Dictionary and Thesaurus (1994), College Edition based on the Random House Webster's College Dictionary (1991) by Random House, Inc. and on the Random House Thesaurus, College Edition, Random House, Inc.

SAger, J. C. (1990): A Practical Course in Terminology Processing, Amsterdam and Philadelphia, John Benjamins.

Saussure, F. de (1916): Cours de linguistique générale, Paris, Payot.

Wanner, L. (1996a): Lexical Functions in Lexicography and Natural Language Processing, Amsterdam and Philadelphia, John Benjamins.

— (1996b): "Introduction," Recent Trends in Meaning-Text Theory (L. WAnner, ed.), Amsterdam and Philadelphia, John Benjamins, pp. 1-36.

Wright, S. E. (1997): "Representation of Concept Systems," Handbook of Terminology Management (S. E. Wright and G. Budin, eds.), Amsterdam and Philadelphia, John Benjamins, pp. 89-97. 